\title{
Classification of wines according to several factors by ICP-MS multi-element analysis
}

\author{
E.P. Pérez-Álvarez ${ }^{\mathrm{a}, *}$, R. Garcia ${ }^{\mathrm{b}, \mathrm{c}}$, P. Barrulas ${ }^{\mathrm{d}}$, C. Dias ${ }^{\mathrm{d}}$, M.J. Cabrita ${ }^{\mathrm{e}, *}$, T. Garde-Cerdán ${ }^{\mathrm{a}}$ \\ a Instituto de Ciencias de la Vid y del Vino (Gobierno de La Rioja, CSIC, Universidad de La Rioja), Carretera de Burgos, km. 6, 26007 Logroño, Spain \\ ${ }^{\mathrm{b}}$ ICAAM - Instituto de Ciências Agrárias e Ambientais Mediterrânicas, IIFA, Universidade de Évora, Núcleo da Mitra, Ap. 94, 7006-554 Évora, Portugal \\ ' LAQV, REQUIMTE, Departamento de Química, Faculdade de Ciências e Tecnologia, Universidade Nova de Lisboa, 2829-516 Caparica, Portugal \\ d Laboratório HERCULES, Universidade de Évora, Palácio do Vimioso, Largo Marquês de Marialva 8, 7000-809 Évora, Portugal \\ e Departamento de Fitotecnia, Escola de Ciências e Tecnologia, ICAAM - Instituto de Ciências Agrárias e Ambientais Mediterrânicas, Universidade de Évora, Núcleo da \\ Mitra, Ap. 94, 7006-554 Évora, Portugal
}

\section{A R T I C L E I N F O}

\section{Keywords:}

ICP-MS

Multi-element analysis

Method optimization

Wine classification

\begin{abstract}
A B S T R A C T
Wines from different grape varieties, geographical zones, soil types, foliar $\mathrm{N}$ application, $\mathrm{SO}_{2}$ addition and oak ageing were analyzed by inductively coupled plasma mass spectrometry (ICP-MS). For this purpose, ICP-MS methodology was optimized. The elements which allowed differentiate wines from studied grape varieties were $\mathrm{Sr}, \mathrm{Ca}, \mathrm{Mg}$ and $\mathrm{Mn}$. Geographical zones were classified according to $\mathrm{Sr}, \mathrm{Ba}, \mathrm{Ni}$, and $\mathrm{Cu}$. $\mathrm{Cs}$ and $\mathrm{Pb}$ were the main elements to discriminate the wines from the 3 soil types. Wines from several $\mathrm{N}$ foliar doses application were classified by $\mathrm{Pb}, \mathrm{Ni}, \mathrm{Mn}$ and $\mathrm{Zn}$. The content of $\mathrm{Cs}, \mathrm{Mg}, \mathrm{Cu}$ and $\mathrm{Pb}$ in wines characterized the $\mathrm{SO}_{2}$ addition. Finally, wines storage in barrels were differentiate by $\mathrm{Na}$ and $\mathrm{Cs}$ concentration. The discriminant functions classify $100 \%$ of the wines, with the exception of grape variety (97.0\%) and oak ageing (95.8\%). Consequently, ICP-MS can be applied to classified wines according to viticultural and oenological factors.
\end{abstract}

\section{Introduction}

Wine is a complex matrix and, it contains low level concentration of mineral elements (the level of the major elements, $\mathrm{Ca}, \mathrm{K}, \mathrm{Mg}, \mathrm{Na}$, and $\mathrm{Mg}$ usually ranged between 10 and $1000 \mathrm{mg} / \mathrm{L}$, minor elements such as $\mathrm{Al}, \mathrm{Fe}, \mathrm{Cu}, \mathrm{Mn}, \mathrm{Rb}, \mathrm{Sr}$, and $\mathrm{Zn}$ are present in the range of 0.1 to $10 \mathrm{mg} / \mathrm{L}$ and trace elements, including $\mathrm{Ba}, \mathrm{Cd}, \mathrm{Co}, \mathrm{Cr}, \mathrm{Li}, \mathrm{Ni}, \mathrm{Pb}$, and $\mathrm{V}$ are in the range of $0.1-1000 \mu \mathrm{g} / \mathrm{L}$ ) (Pohl, 2007). Some of these trace elements, such as $\mathrm{Fe}, \mathrm{Zn}, \mathrm{Cu}, \mathrm{Cr}$, and $\mathrm{Se}$, are essential for the human organism in that they form an integral part of one or more enzymes involved in a metabolic or biochemical process (Pan, Tang, Chen, Wu, \& Han, 2013). Elements are also important for efficient alcoholic fermentation and for the prosthetic metallo-enzyme activation of yeast (Rodríguez Mozaz, García Sotro, Garrido Segovia, \& Ancín Azpilicueta, 1999). In addition, minerals can contribute to stability and clarity in the wine and its color, and they may affect the organoleptic characteristics of the wine, mainly Zn and Fe (Iglesias, Besalú, \& Anticó, 2007), or wine conservation, i.e. precipitation of K and Ca tartrates (McKinnon \& Scollary, 1997). Wine minerals are useful because of the possibility of toxicological risk, such as Cd and Pb (Lara, Cerutti, Salonia, Olsina, \& Martinez, 2005) and food regulations (Frías, Conde, Rodríguez, Dohnal, \& Pérez-Trujillo, 2002).
Mineral content in wines depends on diverse factors: i) natural sources, which reflect the vineyard soil geochemistry and represent the uptake of minerals from soils (Kment et al., 2005). For instance, vineyards located near coastal areas may be influenced by wind from sea or ocean (González-Hernández, Hardisson de La Torre, \& Arias Léon, 1996; Frías, Pérez Trujillo, Peña, \& Conde, 2001; Sauvage, Frank, Stearne, \& Millikan, 2002; Frías, Conde, Rodríguez-Bencomo, GarcíaMontelongo, \& Pérez-Trujillo, 2003); ii) external contamination of the grapevine during growth (from inorganic pesticides, herbicides, fungicides and fertilizers applications, plant protection practices or from environmental pollution (Álvarez, Moreno, Jos, Cameán, \& González, 2007; Fiket, Mikac, \& Kniewald, 2011; Kment et al., 2005; Pohl, 2007); iii) contamination during the winemaking process (prolonged contact with the materials from which pipes, casks and barrels are made, use of additives, fining and clarifying substances...) (Jakubowski, Brandt, Stuewer, Eschnauer, \& Görtges, 1999; Fiket et al., 2011; Kment et al., 2005; Lara et al., 2005; Rusjan, Strlič, Pucko, Šelih, \& Korošec-Koruza, 2006; Pohl, 2007; Kruzlicova, Fiket, \& Kniewald, 2013); and iv) grape maturity and variety, and climatic conditions (González-Hernández et al., 1996). Therefore, knowledge of the mineral content in wines is a growing concern for both consumers and producers (Pohl, 2007).

\footnotetext{
* Corresponding authors.

E-mail addresses: evapipeal@msn.com (E.P. Pérez-Álvarez), mjbc@uevora.pt (M.J. Cabrita).
} 
Usually, atomic absorption spectrometry (AAS), atomic emission spectrometry (AES), inductively coupled plasma mass spectrometry (ICP-MS) and inductively coupled plasma optical emission spectrometry (ICP-OES) are the analytical methods used for the determination of elements in foods (Orvini, Speziali, Salvini, \& Herborg, 2000). Multielemental analysis in wines, ICP-MS is the most versatile technique, which provides high detection power (due to low detection limits) and high selectivity and sensitivity (Eschnauer, Jakob, Meierer, \& Neeb, 1989; Thiel \& Danzer, 1997; Murányi \& Papp, 1998; Murányi \& Kovács, 2000; Castiñeira Gómez, Brandt, Jakubowski, \& Andersson, 2004; Jos, Moreno, González, Repetto, \& Cameán, 2004; Šperková \& Suchánek, 2005; Ivanova-Petropulos et al., 2013, 2015). This technique offers the advantage of analyzing several elements that are present in low concentration in wines at the same time thus considerably shortening the length of time taken for analysis (Williams, Jarvis, \& Wills, 1992).

Taking into consideration that wine is a complex water-ethanol mixture, containing various inorganic and organic substances at different levels (Álvarez et al., 2007; Pyrzynska, 2007; Gonzálvez, Armenta, Pastor, \& De La Guardia, 2008; Moreno et al., 2008; Voica, Dehelean, \& Pamula, 2009; Rodrigues et al., 2011), the largest matrix effects of the samples must be eliminated before the ICP-MS analysis is carried out. For this reason, the stage of pre-treatment of samples in wine mineral analysis can be time-consuming, labor-intensive, and prone to potential contamination problems, as it is a very delicate stage and one that must be properly carried out. The preparation of wine samples for mineral elements determination includes microwave-assisted acid digestion, UV-assisted digestion, thermal digestion in an open reactor, sample dilution, dry and wet ashing, and also less common approaches such as de-alcoholization or analyte separation (Gonzálvez et al., 2008; Ivanova-Petropulos et al., 2016). Moreover, when choosing the method of wine sample preparation, one must consider which procedure provides the best results in the shortest time, with minimum losses and contamination risks, consumes the smallest quantities of reagents and samples and generates the smallest amount of residue and waste (Gonzálvez et al., 2008).

Several studies have looked at the use of spectroscopic methods, such as AAS or ICP-MS, for elemental characterization of wines or for testing wine authenticity, in the case of, for example investigating fraud or adulteration (Brescia et al., 2002). In this study, major, minor and trace elements of 34 AOC Rioja wines (red and white) were determined by ICP-MS. Different calibration methodologies (standard addition and external calibration) and two different approaches for the pre-treatment of samples (direct acidic dilution of the wines and digestion procedures) were compared. Moreover, the element content was used in order to classify the wines according to different grape varieties, geographical zones, soil types, foliar nitrogen application, with or without $\mathrm{SO}_{2}$ addition and oak ageing.

\section{Material and methods}

\subsection{Reagents and materials}

All reagents used were of analytical grade. For sample dilution and preparation of standards, ultrapure water was used (18.2 $\mathrm{m} \Omega$, Milli-Q, Millipore-Merck, Darmstadt, Germany). Nitric acid Suprapur ${ }^{\circledast}$ grade (65.0\%, Merck) was used for wine digestion, dilutions and for standard solution preparation. Multi-element certificate standard solution ICPMS-68B-A (100 mg/L) was from High-Purity Standards (Charleston, SC, USA). Tuning solution (ICP-MS Tuning solution), containing $10 \mu \mathrm{g} / \mathrm{L}$ each of $\mathrm{Ce}, \mathrm{Co}, \mathrm{Li}, \mathrm{Tl}$, and $\mathrm{Y}$ in a matrix of $2 \% \mathrm{HNO}_{3}$ (Agilent Technologies, Palo Alto, CA, USA), was used for ICP-MS instrument optimization in order to achieve $\mathrm{CeO}^{+} / \mathrm{Ce}^{+}<2 \%$ and $\mathrm{Ce}^{2+} / \mathrm{Ce}^{+}$ $<3 \%$. The signal was maximized while maintaining $0.9-1.1 \% \mathrm{CeO}^{+} /$ $\mathrm{Ce}^{+}$during tuning. $\mathrm{Ru}, \mathrm{Rh}$, and Ir were used as internal standards for possible instrumental drifts and matrix effects corrections.

\subsection{Wine samples}

A total of 34 wine samples ( 8 whites and 26 reds) were collected from AOC Rioja, Spain. All the wines were elaborated in the same cellar following traditional procedures used in AOC Rioja (Spain) and came from the 2016 vintage, except those aged in barrels, which were elaborated in 2015. The white grape varieties were: Viura and Tempranillo blanco. Tempranillo blanco grapes came from five AOC Rioja grapevine growing zones with different edaphoclimatic conditions (La Grajera (2 wines), Valdegón (1 wine), Cenicero (1 wine), Corera (1 wine), and Alfaro ( 1 wine)), while the Viura grapes came from La Grajera (1 wine). Moreover, a Tempranillo blanco wine from La Grajera was aging in barrels. The red samples were elaborated with Tempranillo, Garnacha, Maturana, and Graciano grape varieties. Tempranillo red wines were from different soils, classified as Fluventic haploxerepts (FH), Typic calcixerepts (TC), and Petrocalcic palexeroll (PP), according to the Soil Survey Staff (2010) classification, and located in Uruñuela (La Rioja). Three wines were elaborated from each of the three soil types (a total of 9 wines). Moreover, urea foliar applications were carried out according to Pérez-Álvarez, Garde-Cerdán, García-Escudero, and MartínezVidaurre (2017), and the treatments were made in triplicate ( 9 wines in total). In addition, wines from Tempranillo, Graciano, Maturana, and Garnacha grape varieties were produced from La Grajera (4 wines). The wines of Tempranillo and Graciano were also aged in barrels (2 wines). Fermentations were carried out without the addition of $\mathrm{SO}_{2}$ in two Tempranillo wines ( 2 wines), one of which was aged in barrels.

\subsection{Sample preparation}

Two different procedures were assayed over the 34 wine samples: acidic wine dilution and acidic digestion. The perfluoroalkoxy (PFA) beakers used for storing and treating the samples were cleaned to avoid contamination by any traces of metal. The containers were treated with $5 \% \mathrm{HNO}_{3}$ and then washed with Milli-Q water.

\subsubsection{Dilution}

Samples were diluted 10 fold for minor and trace elements (Al, Cr, $\mathrm{Mn}, \mathrm{Fe}, \mathrm{Co}, \mathrm{Ni}, \mathrm{Cu}, \mathrm{Zn}, \mathrm{As}, \mathrm{Se}, \mathrm{Sr}, \mathrm{Cd}, \mathrm{Cs}, \mathrm{Ba}$, and $\mathrm{Pb}$ ) and 100 fold for major elements ( $\mathrm{Na}, \mathrm{Mg}, \mathrm{P}, \mathrm{K}$, and $\mathrm{Ca}$ ) with $2 \% \mathrm{HNO}_{3}$, without any prior preparation.

\subsubsection{Digestion}

Wine digestion was carried out in the PFA beakers adding $5 \mathrm{~mL}$ of each wine and $2 \mathrm{~mL}$ of $65 \% \mathrm{HNO}_{3}$; then, the beakers were put on a hotplate between 50 and $70{ }^{\circ} \mathrm{C}$ until the samples became colorless because of the digestion of the acid. Once the digestion step had been completed, the solutions were cooled to room temperature. The tempered samples were transferred to PFA volumetric flasks and fulfilled with Milli-Q water up to $50 \mathrm{~mL}$.

\subsection{ICP-MS analysis}

Multi-element determination was performed on an Agilent 8800 Triple Quadrupole ICP-MS, equiped with a Micromist nebulizer. In accordance with the analytes of interest, the collision/reaction cell was in "no-gas mode", "He mode", "O $\mathrm{O}_{2}$ mode" and " $\mathrm{NH}_{3}$ mode".

Plasma gas flow rate was $15 \mathrm{~L} / \mathrm{min}$ and collision and reaction gases flow rates were $4 \mathrm{~mL} / \mathrm{min}, 0.5 \mathrm{~mL} / \mathrm{min}$ and $1.5 \mathrm{~mL} / \mathrm{min}$ for $\mathrm{He}, \mathrm{O}_{2}$ and $\mathrm{NH}_{3}$, respectively. Analyses were optimized at $1550 \mathrm{~W}$ forward power and $1.1 \mathrm{~L} / \mathrm{min}$ carrier gas flow with no dilution or makeup gas. Sampling depth $(10 \mathrm{~mm})$ and lens parameters were optimized for highest signal and optimum peak shape while maintaining low oxides.

In "no-gas mode", selected masses at Q1/Q2 were 23/23 (Na), 24/ 24 (Mg), 39/39 (K), 101/101 (Ru), 103/103 (Rh), 111/111 (Cd), 115/ 115 (In), 133/133 (Cs), 137/137 (Ba), 139/139 (La), 140/140 (Ce), 141/141 (Pr), 146/146 (Nd), 147/147 (Sm), 153/153 (Eu), 157/157 
(Gd), 166/166 (Er), 169/169 (Tm), 172/172 (Yb), 193/193 (Ir), 208/ $208(\mathrm{~Pb})$, and 209/209 (Bi). In "He mode", selected masses at Q1/Q2 were 23/23 (Na), 24/24 (Mg), 27/27 (Al), 39/39 (K), 45/45 (Sc), 51/ 51 (V), 52/52 (Cr), 55/55 (Mn), 56/56 (Fe), 57/57 (Fe), 59/59 (Co), 60/60 (Ni), 63/63 (Cu), 66/66 (Zn), 78/78 (Se), 88/88 (Sr), 101/101 (Ru), 103/103 (Rh), 111/111 (Cd), 115/115 (In), 133/133 (Cs), 137/ 137 (Ba), 193/193 (Ir), 208/208 (Pb), and 209/209 (Bi). In "O ${ }_{2}$ mode", selected masses at Q1/Q2 were 31/47 (P), 75/91 (As), 101/101 (Ru), 103/103 (Rh), and 193/193 (Ir). And in "NH3 mode", selected masses at Q1/Q2 were 42/42 (Ca), 101/101 (Ru), 103/103 (Rh), and 193/193 (Ir). All the operation modes were with the MS/MS scan type. The number of replicates was 3 and sweeps per replicate were 10 .

Two calibration modes were carried out: external calibration and standard addition calibration. The external calibration was prepared from high purity standards (ICP-MS-68B-A) diluted in synthetic wine (12\% ethanol and $4 \mathrm{~g} / \mathrm{L}$ tartaric acid) and $2 \% \mathrm{HNO}_{3}$, in order to obtain 10 different concentration solutions: $0,1,10,50,100,200,500,1000$, 1500 , and $3000 \mathrm{mg} / \mathrm{L}$. The standard addition calibration was different for minor, trace and for major elements. In the first case, $3 \mathrm{~mL}$ of one of the wine samples were mixed with $2 \% \mathrm{HNO}_{3}$ and the necessary amount of the high purity standards (ICP-MS-68B-A) up to $5 \mathrm{~mL}$ in order to obtain six different concentration solutions: $0,50,100,200,400$, and $800 \mu \mathrm{g} / \mathrm{L}$. For the major elements, also $3 \mathrm{~mL}$ of one of the wine samples were mixed with $2 \% \mathrm{HNO}_{3}$ and the necessary amount of the high purity standards (ICP-MS-68B-A) up to $5 \mathrm{~mL}$ in order to obtain five different concentration solutions: $0,500,1000,2000$, and $4000 \mathrm{mg} / \mathrm{L}$. Both calibration modes, external and standard addition, were employed for dilution and digestion sample procedures. The limits of detection (LOD) and quantification (LOQ) of the different elements analyzed are shown in Tables S1 and S2.

\subsection{Statistical analysis}

A statistical analysis on mineral elements (major, minor, and trace) of red, white and all wines together was performed using variance analysis (one-way ANOVA) using SPSS Version 21.0 (Chicago, USA). Differences between averages were compared using the Duncan test at 0.05 probability level. Discriminant analyses were carried out on data showing the concentration of elements found in the wines in order to classify them according to several factors: red and white wines from different grape varieties, geographical zones, soil types, foliar nitrogen application, with or without $\mathrm{SO}_{2}$ addition, and oak ageing.

\section{Results and discussion}

\subsection{Optimization of sample preparation and quantification method}

Table $S 3$ shows the mean, the minimum and the maximum contents of the major elements obtained in the 34 wine samples. Each of these wines underwent both sample preparations, dilution and digestion, and both calibration methods. The results indicated that the digestion sample preparation with the standard addition (GSA) was the best for $\mathrm{Mg}, \mathrm{K}$, and $\mathrm{Ca}$, due to their content in the wines was the highest; and also for $\mathrm{P}$ but without significant differences in the dilution sample preparation with standard addition (LSA). In the case of Na, there were no significant differences between the four approaches. Considering only the white samples (Table 1), GSA was the best methodology for $\mathrm{Mg}$, and $\mathrm{Ca}$ determination. In the case of P concentration, GSA was better than dilution sample preparation with the external calibration (LEC) but without significant differences with respect to the digestion sample preparation with the external calibration (GEC) and LSA. Potassium content was higher in GSA than in LEC and LSA, but with no differences with GEC approach. For Na concentration, there were no significant differences between the four approaches. Regarding the major elements in red wines (Table 2), in all the elements the best approach was GSA, except for P, in which GSA methodology was
Table 1

Results of the major elements $(\mathrm{mg} / \mathrm{L})$ in white wines $(\mathrm{n}=8)$.

\begin{tabular}{llllll}
\hline & & LEC & GEC & LSA & GSA \\
\hline Na & Mean & $12.76 \mathbf{a}$ & $17.84 \mathbf{a}$ & $17.68 \mathbf{a}$ & $20.45 \mathbf{a}$ \\
& SD & 12.46 & 13.01 & 12.99 & 15.02 \\
& Minimum & 0.90 & 4.91 & 5.16 & 6.72 \\
& Maximum & 35.50 & 41.90 & 41.12 & 48.12 \\
$\mathrm{Mg}$ & Mean & $84.82 \mathbf{a}$ & $90.28 \mathbf{a}$ & $87.23 \mathbf{a}$ & $114.64 \mathbf{b}$ \\
& SD & 10.08 & 10.70 & 11.47 & 14.68 \\
& Minimum & 69.50 & 73.24 & 75.04 & 99.80 \\
& Maximum & 103.88 & 109.23 & 111.52 & 144.38 \\
$\mathbf{P}$ & Mean & $29.13 \mathbf{a}$ & $48.55 \mathbf{a b}$ & $55.25 \mathbf{a b}$ & $62.26 \mathbf{b}$ \\
& SD & 14.13 & 24.14 & 26.77 & 30.01 \\
& Minimum & 12.23 & 20.24 & 23.30 & 25.64 \\
& Maximum & 53.97 & 89.69 & 101.29 & 114.33 \\
$\mathbf{K}$ & Mean & $539.62 \mathbf{a}$ & $586.51 \mathbf{a b}$ & $485.91 \mathbf{a}$ & $688.60 \mathbf{b}$ \\
& SD & 104.90 & 119.64 & 92.57 & 135.80 \\
& Minimum & 463.04 & 481.92 & 420.09 & 574.59 \\
& Maximum & 780.57 & 836.23 & 693.96 & 967.33 \\
& Mean & $51.54 \mathbf{a}$ & $49.13 \mathbf{a}$ & $53.65 \mathbf{a}$ & $63.98 \mathbf{b}$ \\
$\mathbf{C}$ & Ma & 8.98 & 9.40 & 8.93 & 12.15 \\
& SD & 35.47 & 34.32 & 39.78 & 44.52 \\
& Minimum & 62.44 & 61.55 & 64.49 & 79.46 \\
& Maximum & 62.49 & & \\
\hline
\end{tabular}

LEC: sample dilution and element quantification by external calibration. GEC: sample digestion and element quantification by external calibration. LSA: sample dilution and element quantification by standard addition. GSA: sample digestion and element quantification by standard addition. SD: standard deviation. For each element, different letters indicate significant differences between sample preparation procedures and quantification methods ( $\mathrm{p} \leq 0.05$ ).

Table 2

Results of the major elements $(\mathrm{mg} / \mathrm{L})$ in red wines $(\mathrm{n}=26)$.

\begin{tabular}{|c|c|c|c|c|c|}
\hline & & LEC & GEC & LSA & GSA \\
\hline \multirow[t]{4}{*}{$\mathrm{Na}$} & Mean & $3.20 \mathrm{a}$ & $6.45 \mathbf{a}$ & $6.43 \mathrm{a}$ & $7.33 \mathbf{a}$ \\
\hline & SD & 6.19 & 6.98 & 6.94 & 8.22 \\
\hline & Minimum & $<$ LOQ & 1.99 & 1.90 & 2.00 \\
\hline & Maximum & 22.14 & 26.81 & 26.04 & 31.25 \\
\hline \multirow[t]{4}{*}{$\mathrm{Mg}$} & Mean & $78.74 \mathbf{a}$ & 80.40 a & 80.15 a & 104.97 b \\
\hline & SD & 21.87 & 18.95 & 21.57 & 26.17 \\
\hline & Minimum & 47.97 & 55.55 & 52.02 & 69.28 \\
\hline & Maximum & 131.69 & 116.60 & 132.55 & 155.13 \\
\hline \multirow[t]{4}{*}{$\mathrm{P}$} & Mean & $69.32 \mathbf{a}$ & 110.86 b & 129.58 bc & $142.07 \mathrm{c}$ \\
\hline & SD & 25.05 & 35.17 & 46.64 & 44.77 \\
\hline & Minimum & 33.94 & 56.91 & 66.18 & 72.51 \\
\hline & Maximum & 134.73 & 164.22 & 261.54 & 210.97 \\
\hline \multirow[t]{4}{*}{ K } & Mean & $1112.46 \mathrm{ab}$ & $1167.60 \mathrm{~b}$ & 988.09 a & $1371.67 \mathrm{c}$ \\
\hline & SD & 282.52 & 224.87 & 233.56 & 268.57 \\
\hline & Minimum & 859.71 & 735.18 & 739.67 & 904.25 \\
\hline & Maximum & 2125.45 & 1762.73 & 1776.94 & 2159.68 \\
\hline \multirow[t]{4}{*}{$\mathrm{Ca}$} & Mean & 67.72 b & 59.89 a & $66.81 \mathrm{~b}$ & 77.52 c \\
\hline & $\mathrm{SD}$ & 12.58 & 10.42 & 13.76 & 12.67 \\
\hline & Minimum & 36.93 & 35.01 & 37.46 & 46.03 \\
\hline & Maximum & 92.01 & 76.25 & 98.50 & 94.86 \\
\hline
\end{tabular}

LEC: sample dilution and element quantification by external calibration. GEC: sample digestion and element quantification by external calibration. LSA: sample dilution and element quantification by standard addition. GSA: sample digestion and element quantification by standard addition. SD: standard deviation. LOQ: limit of quantification. For each element, different letters indicate significant differences between sample preparation procedures and quantification methods ( $\mathrm{p} \leq 0.05$ ).

similar to the LSA one. In the case of Na, significant differences between the four approaches were not found.

Only 15 minor and trace elements were found in the wines out of a total of 29 minor and trace elements searched for (Table S4), as 14 elements were not found in the wines: Sc, V, In, La, Ce, Pr, Nd, Sm, Eu, $\mathrm{Gd}, \mathrm{Er}, \mathrm{Tm}, \mathrm{Yb}$, and $\mathrm{Bi}$. For $\mathrm{Al}$, the best approach was the digestion of 
Table 3

Results of the minor and trace elements $(\mu \mathrm{g} / \mathrm{L})$ in white wines $(n=8)$.

\begin{tabular}{|c|c|c|c|c|c|}
\hline & & LEC & GEC & LSA & GSA \\
\hline \multirow[t]{4}{*}{$\mathrm{Al}$} & Mean & $32.81 \mathrm{a}$ & 85.91 a & $53.41 \mathrm{a}$ & 87.76 a \\
\hline & SD & 76.04 & 64.92 & 83.08 & 105.51 \\
\hline & Minimum & $<\mathrm{LOQ}$ & 41.24 & $<$ LOQ & $<\mathrm{LOQ}$ \\
\hline & Maximum & 219.28 & 219.93 & 255.72 & 330.13 \\
\hline \multirow[t]{4}{*}{$\mathrm{Cr}$} & Mean & $6.53 \mathbf{a}$ & $8.58 \mathrm{ab}$ & $10.57 \mathbf{b}$ & $8.66 \mathrm{ab}$ \\
\hline & SD & 2.47 & 2.09 & 3.02 & 3.01 \\
\hline & Minimum & 2.89 & 6.50 & 6.85 & 4.42 \\
\hline & Maximum & 9.15 & 12.88 & 14.81 & 13.53 \\
\hline \multirow[t]{4}{*}{$\mathrm{Mn}$} & Mean & $666.74 \mathbf{a}$ & $579.72 \mathbf{a}$ & $687.47 \mathbf{a}$ & $662.25 \mathrm{a}$ \\
\hline & SD & 193.51 & 125.44 & 152.17 & 147.34 \\
\hline & Minimum & 414.73 & 381.09 & 438.59 & 429.03 \\
\hline & Maximum & 1030.30 & 792.69 & 947.13 & 916.11 \\
\hline \multirow[t]{4}{*}{$\mathrm{Fe}$} & Mean & 293.97 a & $415.39 \mathbf{a}$ & $410.20 \mathrm{a}$ & $385.74 \mathbf{a}$ \\
\hline & SD & 362.48 & 340.40 & 323.32 & 309.28 \\
\hline & Minimum & $<$ LOQ & 152.42 & 135.67 & 119.47 \\
\hline & Maximum & 1048.01 & 1086.96 & 1056.56 & 984.89 \\
\hline \multirow[t]{4}{*}{ Co } & Mean & $1.19 \mathrm{a}$ & $1.35 \mathrm{a}$ & $0.78 \mathrm{a}$ & $0.61 \mathbf{a}$ \\
\hline & SD & 1.21 & 0.99 & 0.82 & 0.95 \\
\hline & Minimum & 0.35 & 0.50 & 0.08 & $<\mathrm{LOQ}$ \\
\hline & Maximum & 3.92 & 3.42 & 2.62 & 2.51 \\
\hline \multirow[t]{4}{*}{$\mathrm{Ni}$} & Mean & $7.96 \mathbf{a b}$ & $6.28 \mathrm{a}$ & $8.52 \mathrm{~b}$ & $6.84 \mathrm{ab}$ \\
\hline & SD & 1.33 & 1.81 & 2.16 & 1.76 \\
\hline & Minimum & 6.30 & 3.88 & 5.80 & 4.94 \\
\hline & Maximum & 9.97 & 8.20 & 11.28 & 9.59 \\
\hline \multirow[t]{4}{*}{$\mathrm{Cu}$} & Mean & $101.04 \mathbf{a}$ & $91.16 \mathbf{a}$ & $97.74 \mathbf{a}$ & $93.80 \mathbf{a}$ \\
\hline & SD & 56.38 & 46.61 & 50.70 & 48.25 \\
\hline & Minimum & 12.96 & 13.25 & 12.77 & 13.68 \\
\hline & Maximum & 176.31 & 151.60 & 162.40 & 154.26 \\
\hline \multirow[t]{4}{*}{$\mathrm{Zn}$} & Mean & 304.55 a & 286.86 a & $322.83 \mathrm{a}$ & $305.82 \mathbf{a}$ \\
\hline & SD & 127.47 & 87.03 & 116.55 & 98.77 \\
\hline & Minimum & 164.39 & 168.16 & 158.07 & 181.83 \\
\hline & Maximum & 597.56 & 459.68 & 568.32 & 516.12 \\
\hline \multirow[t]{4}{*}{ As } & Mean & $10.18 \mathrm{c}$ & $2.41 \mathrm{a}$ & $6.77 \mathbf{b}$ & $3.57 \mathbf{a}$ \\
\hline & SD & 3.45 & 1.76 & 1.72 & 1.26 \\
\hline & Minimum & 6.42 & 1.32 & 5.70 & 2.41 \\
\hline & Maximum & 16.54 & 6.45 & 10.91 & 6.54 \\
\hline \multirow[t]{4}{*}{$\mathrm{Se}$} & Mean & $11.10 \mathrm{~b}$ & $2.83 \mathrm{a}$ & $4.19 \mathbf{a}$ & $1.28 \mathrm{a}$ \\
\hline & SD & 7.84 & 5.08 & 3.69 & 2.44 \\
\hline & Minimum & 2.09 & $<\mathrm{LOQ}$ & $<$ LOQ & $<\mathrm{LOQ}$ \\
\hline & Maximum & 22.99 & 11.10 & 11.50 & 6.17 \\
\hline \multirow[t]{4}{*}{$\mathrm{Sr}$} & Mean & $1314.35 \mathbf{a}$ & $1316.32 \mathbf{a}$ & $1270.31 \mathbf{a}$ & $1245.70 \mathrm{a}$ \\
\hline & SD & 596.93 & 599.55 & 574.63 & 573.84 \\
\hline & Minimum & 644.16 & 697.90 & 692.27 & 644.25 \\
\hline & Maximum & 2558.77 & 2631.17 & 2546.37 & 2527.01 \\
\hline \multirow[t]{4}{*}{$\mathrm{Cd}$} & Mean & $0.21 \mathrm{a}$ & $0.36 \mathrm{~b}$ & $0.06 \mathrm{a}$ & $0.09 \mathbf{a}$ \\
\hline & SD & 0.14 & 0.20 & 0.11 & 0.11 \\
\hline & Minimum & $<\mathrm{LOQ}$ & 0.20 & $<\mathrm{LOQ}$ & $<\mathrm{LOQ}$ \\
\hline & Maximum & 0.40 & 0.71 & 0.30 & 0.32 \\
\hline \multirow[t]{4}{*}{ Cs } & Mean & $3.10 \mathrm{a}$ & $2.69 \mathrm{a}$ & $2.56 \mathrm{a}$ & $2.82 \mathrm{a}$ \\
\hline & $\mathrm{SD}$ & 2.35 & 2.29 & 2.16 & 2.39 \\
\hline & Minimum & 0.19 & 0.02 & 0.04 & $<\mathrm{LOQ}$ \\
\hline & Maximum & 6.72 & 6.61 & 5.64 & 6.58 \\
\hline \multirow[t]{4}{*}{$\mathrm{Ba}$} & Mean & 38.74 a & $23.55 \mathrm{a}$ & $42.24 \mathrm{a}$ & $35.67 \mathbf{a}$ \\
\hline & SD & 20.09 & 17.69 & 22.27 & 22.47 \\
\hline & Minimum & 18.68 & 7.13 & 20.51 & 13.77 \\
\hline & Maximum & 72.95 & 55.00 & 86.70 & 77.72 \\
\hline \multirow[t]{4}{*}{$\mathrm{Pb}$} & Mean & $3.75 \mathbf{a}$ & $4.68 \mathbf{a}$ & $3.07 \mathrm{a}$ & $4.12 \mathbf{a}$ \\
\hline & $\mathrm{SD}$ & 2.73 & 2.26 & 2.62 & 2.69 \\
\hline & Minimum & 1.44 & 2.42 & 0.93 & 1.20 \\
\hline & Maximum & 10.06 & 9.27 & 8.76 & 9.57 \\
\hline
\end{tabular}

LEC: sample dilution and element quantification by external calibration. GEC: sample digestion and element quantification by external calibration. LSA: sample dilution and element quantification by standard addition. GSA: sample digestion and element quantification by standard addition. SD: standard deviation. LOQ: limit of quantification. For each element, different letters indicate significant differences between sample preparation procedures and quantification methods ( $\mathrm{p} \leq 0.05)$. the samples. In the case of $\mathrm{Cr}$, the best was the standard addition but with no significant differences between GEC and GSA. Concentration of $\mathrm{Co}$, Se, and $\mathrm{Cd}$ was higher when external calibration was carried out as opposed to standard addition, with the exception of LEC for Co that did not show differences with the standard addition. The concentration of As in the wines presented differences between the four approaches, being from the best to the worst methods LSA, LEC, GSA and GEC. The GEC methodology showed the lowest concentration of Ba, with no differences between the other three approaches. The concentration of the other 8 minor and trace elements found in the wines (Mn, $\mathrm{Fe}, \mathrm{Ni}$, $\mathrm{Cu}, \mathrm{Zn}, \mathrm{Sr}, \mathrm{Cs}$, and $\mathrm{Pb}$ ) did not show differences between the four approaches studied (Table S4).

Regarding the concentration of minor and trace elements in the white wines (Table 3), LSA showed the highest $\mathrm{Cr}$ and Ni content but without significant differences with GEC and GSA in the case of $\mathrm{Cr}$ and with LEC and GSA in the case of Ni. Arsenic content presented higher values in dilution sample preparation than in digestion. LEC was the best method for Se determination, while DEG was the best for Cd quantification. The concentration of the other 10 minor and trace elements found in the white wines (Al, Mn, Fe, $\mathrm{Co}, \mathrm{Cu}, \mathrm{Zn}, \mathrm{Sr}, \mathrm{Cs}, \mathrm{Ba}$, and $\mathrm{Pb}$ ) did not show differences between the four approaches studied (Table 3).

With respect to the red wines (Table 4), Al concentration had the highest values for digestion. The standard addition was the best method for $\mathrm{Cr}$ determination although with no significant differences with respect to GEC approach. Dilution sample preparation was the best in the case of As concentration. The best method for Se and Cd quantification was the external calibration. GEC was the worst approach for Ba determination. The concentration of the other 9 minor and trace elements found in the red wines ( $\mathrm{Mn}, \mathrm{Fe}, \mathrm{Co}, \mathrm{Ni}, \mathrm{Cu}, \mathrm{Zn}, \mathrm{Sr}, \mathrm{Cs}$, and $\mathrm{Pb}$ ) did not show differences between the four approaches studied (Table 4).

Iglesias et al. (2007) also observed significant differences in element concentration between seven techniques used, except in the case of $\mathrm{Cu}$ concentration. They argued that after direct measurements of the wine sample, the calibration graphs obtained with aqueous standards are higher than the results obtained with other treatments, confirming the existence of a matrix effect in the wines. In the same way, Cocchi et al. (2004) show the influence of the organic components when direct method is used, although this could be avoided by adding ethanol.

\subsection{Multi-element wine content}

Among the major elements, $\mathrm{K}$ was the most concentrated in wines (Table S3), ranging from $420.09 \mathrm{mg} / \mathrm{L}$ in white wine (Table 1) to $2159.68 \mathrm{mg} / \mathrm{L}$ in red wine (Table 2); whilst Na was the major element with the lowest concentration in wines (Table S3), ranging from < LOQ in red wine (Table 2) to $48.12 \mathrm{mg} / \mathrm{L}$ in white wine (Table 1). These results were in agreement with Frías et al. (2001) and Jos et al. (2004). The remaining major elements were found at intermediate concentrations (Tables S3, 1 and 2). Regarding the difference between white and red wines, all major elements, except $\mathrm{Mg}$, showed significant differences ( $\mathrm{p} \leq 0.05$ ) with a higher concentration in red wines, except $\mathrm{Na}$, where content was higher in white wines.

With regard to the minor and trace elements, Sr was the element that presented the highest concentration in wines (Table S4), with a range between $157.88 \mu \mathrm{g} / \mathrm{L}$ in red wine and 3,818.88 $\mu \mathrm{g} / \mathrm{L}$ also in red wine (Table 4); the element found in lowest concentration was Co (Table S4), where concentration ranged between $<$ LOQ, in both, red and white wines (Tables 3 and 4), and $3.92 \mu \mathrm{g} / \mathrm{L}$ in white wine (Table 3). Comparing red and white wines, the Co content was significantly higher in white wines than in red ( $\mathrm{p} \leq 0.05)$, whilst the Al, $\mathrm{Fe}, \mathrm{Ni}, \mathrm{Ba}$, and $\mathrm{Pb}$ concentration was higher in red wines than in white $(\mathrm{p} \leq 0.05)$. The remaining minor and trace elements did not show significant differences between either types of wine ( $p \leq 0.05)$.

Orescanin, Katunar, Kutle, and Valkovic (2003) and Coetzee, van Jaarsveld, and Vanhaecke (2014) observed higher concentration of 
Table 4

Results of the minor and trace elements $(\mu \mathrm{g} / \mathrm{L})$ in red wines $(\mathrm{n}=26)$.

\begin{tabular}{|c|c|c|c|c|c|}
\hline & & LEC & GEC & LSA & GSA \\
\hline \multirow[t]{4}{*}{$\mathrm{Al}$} & Mean & $115.08 \mathbf{a}$ & 215.34 b & $138.06 \mathbf{a}$ & $203.48 \mathrm{~b}$ \\
\hline & SD & 71.08 & 78.77 & 66.96 & 86.81 \\
\hline & Minimum & 3.78 & 82.47 & 34.31 & 87.76 \\
\hline & Maximum & 308.61 & 375.71 & 346.15 & 451.32 \\
\hline \multirow[t]{4}{*}{$\mathrm{Cr}$} & Mean & $6.07 \mathrm{a}$ & $7.66 \mathrm{ab}$ & $10.02 \mathbf{b}$ & 9.64 b \\
\hline & SD & 3.57 & 3.77 & 3.95 & 5.14 \\
\hline & Minimum & 1.32 & 3.06 & 5.48 & 4.17 \\
\hline & Maximum & 14.71 & 17.38 & 19.73 & 23.40 \\
\hline \multirow[t]{4}{*}{ Mn } & Mean & $660.91 \mathbf{a}$ & $704.57 \mathbf{a}$ & $684.22 \mathbf{a}$ & $753.02 \mathbf{a}$ \\
\hline & SD & 326.52 & 409.36 & 344.30 & 405.85 \\
\hline & Minimum & 350.70 & 335.13 & 375.54 & 396.75 \\
\hline & Maximum & 1552.81 & 1813.01 & 1671.29 & 1916.57 \\
\hline \multirow[t]{4}{*}{$\mathrm{Fe}$} & Mean & 677.89 a & 854.98 a & 820.21 a & 967.35 a \\
\hline & SD & 453.48 & 482.79 & 485.46 & 595.90 \\
\hline & Minimum & 227.51 & 275.62 & 382.42 & 291.69 \\
\hline & Maximum & 2170.66 & 2406.52 & 2401.55 & 2915.01 \\
\hline \multirow[t]{4}{*}{ Co } & Mean & $0.47 \mathbf{a}$ & $0.55 \mathrm{a}$ & $0.24 \mathrm{a}$ & $0.27 \mathrm{a}$ \\
\hline & SD & 0.58 & 0.57 & 0.43 & 0.63 \\
\hline & Minimum & $<\mathrm{LOQ}$ & $<\mathrm{LOQ}$ & $<$ LOQ & $<\mathrm{LOQ}$ \\
\hline & Maximum & 2.55 & 2.52 & 1.81 & 2.76 \\
\hline \multirow[t]{4}{*}{$\mathrm{Ni}$} & Mean & $8.94 \mathbf{a}$ & $9.79 \mathrm{a}$ & $8.64 \mathbf{a}$ & $10.14 \mathbf{a}$ \\
\hline & SD & 3.97 & 5.45 & 4.01 & 5.08 \\
\hline & Minimum & 4.67 & 4.07 & 4.41 & 4.29 \\
\hline & Maximum & 20.60 & 25.78 & 21.26 & 25.18 \\
\hline \multirow[t]{4}{*}{$\mathrm{Cu}$} & Mean & 87.05 a & $102.93 \mathbf{a}$ & 82.64 a & 100.64 a \\
\hline & SD & 53.43 & 59.39 & 48.80 & 50.06 \\
\hline & Minimum & 18.35 & 25.30 & 18.75 & 24.92 \\
\hline & Maximum & 216.22 & 241.21 & 200.11 & 237.68 \\
\hline \multirow[t]{4}{*}{$\mathrm{Zn}$} & Mean & 249.18 a & 293.85 a & $261.90 \mathbf{a}$ & 285.68 a \\
\hline & $\mathrm{SD}$ & 383.78 & 437.07 & 396.77 & 422.25 \\
\hline & Minimum & 1.59 & 33.86 & 13.13 & 28.31 \\
\hline & Maximum & 1476.76 & 1712.87 & 1560.78 & 1694.71 \\
\hline \multirow[t]{4}{*}{ As } & Mean & $5.24 \mathrm{c}$ & $2.65 \mathrm{a}$ & $7.62 \mathrm{~d}$ & $4.00 \mathrm{~b}$ \\
\hline & SD & 0.70 & 0.75 & 1.63 & 0.71 \\
\hline & Minimum & 4.26 & 1.14 & 5.10 & 2.42 \\
\hline & Maximum & 6.66 & 4.64 & 11.15 & 5.38 \\
\hline \multirow[t]{4}{*}{$\mathrm{Se}$} & Mean & $5.59 \mathrm{~b}$ & $4.96 \mathrm{~b}$ & $1.62 \mathrm{a}$ & $1.03 \mathrm{a}$ \\
\hline & SD & 3.82 & 4.04 & 2.81 & 1.95 \\
\hline & Minimum & $<\mathrm{LOQ}$ & $<\mathrm{LOQ}$ & $<\mathrm{LOQ}$ & $<\mathrm{LOQ}$ \\
\hline & Maximum & 12.54 & 13.67 & 11.50 & 8.22 \\
\hline \multirow[t]{4}{*}{$\mathrm{Sr}$} & Mean & $899.69 \mathbf{a}$ & $895.48 \mathrm{a}$ & $881.54 \mathbf{a}$ & 965.93 a \\
\hline & SD & 1072.81 & 1070.37 & 1062.51 & 1180.36 \\
\hline & Minimum & 161.32 & 165.93 & 157.88 & 180.20 \\
\hline & Maximum & 3423.07 & 3390.85 & 3428.44 & 3818.88 \\
\hline \multirow[t]{4}{*}{$\mathrm{Cd}$} & Mean & $0.18 \mathrm{~b}$ & $0.34 \mathrm{c}$ & $0.03 \mathrm{a}$ & $0.03 \mathrm{a}$ \\
\hline & SD & 0.18 & 0.19 & 0.06 & 0.09 \\
\hline & Minimum & $<\mathrm{LOQ}$ & 0.04 & $<$ LOQ & $<\mathrm{LOQ}$ \\
\hline & Maximum & 0.68 & 0.95 & 0.26 & 0.37 \\
\hline \multirow[t]{4}{*}{ Cs } & Mean & $3.41 \mathbf{a}$ & $3.48 \mathbf{a}$ & $2.83 \mathrm{a}$ & $3.81 \mathbf{a}$ \\
\hline & SD & 2.62 & 2.86 & 2.68 & 3.19 \\
\hline & Minimum & 1.14 & 0.93 & 0.75 & 1.01 \\
\hline & Maximum & 12.51 & 13.14 & 12.09 & 14.50 \\
\hline \multirow[t]{4}{*}{$\mathrm{Ba}$} & Mean & 65.07 b & 53.14 a & $70.10 \mathbf{b}$ & $71.41 \mathrm{~b}$ \\
\hline & $\mathrm{SD}$ & 14.86 & 16.27 & 16.72 & 19.15 \\
\hline & Minimum & 37.13 & 19.30 & 39.29 & 34.42 \\
\hline & Maximum & 110.38 & 99.58 & 119.43 & 128.68 \\
\hline \multirow[t]{4}{*}{$\mathrm{Pb}$} & Mean & $7.37 \mathbf{a}$ & $8.70 \mathrm{a}$ & $7.20 \mathrm{a}$ & $8.54 \mathbf{a}$ \\
\hline & $\mathrm{SD}$ & 9.72 & 9.22 & 10.15 & 10.89 \\
\hline & Minimum & 1.29 & 2.48 & 0.49 & 1.15 \\
\hline & Maximum & 41.72 & 39.17 & 40.39 & 44.28 \\
\hline
\end{tabular}

LEC: sample dilution and element quantification by external calibration. GEC: sample digestion and element quantification by external calibration. LSA: sample dilution and element quantification by standard addition. GSA: sample digestion and element quantification by standard addition. SD: standard deviation. LOQ: limit of quantification. For each element, different letters indicate significant differences between sample preparation procedures and quantification methods ( $\mathrm{p} \leq 0.05)$. trace elements in red wine than in white. They argued that this is because the grapeskin contact is longer in the red winemaking process and the skins contain a higher a concentration of the trace element than must.

All the samples presented levels for toxic elements such as As, Cd, $\mathrm{Cu}, \mathrm{Pb}$ and $\mathrm{Zn}$ below the maximal concentration allowed for them in wines (As: $0.2 \mathrm{mg} / \mathrm{L}, \mathrm{Cd}: 10 \mu \mathrm{g} / \mathrm{L}, \mathrm{Cu}: 1 \mathrm{mg} / \mathrm{L}, \mathrm{Pb}: 0.15 \mathrm{mg} / \mathrm{L}$ and $\mathrm{Zn}$ : $5 \mathrm{mg} / \mathrm{L}$ (Ivanova-Petropulos et al., 2016)).

\subsection{Classification of wines according to several factors by their multi- elemental content determined using ICP-MS}

\subsubsection{ICP-MS classification of wines according to their grape variety}

To classify the wines produced with different grape varieties (Tempranillo blanco, Tempranillo, Viura, Graciano, Maturana, and Garnacha), discriminant analysis was performed on data and then expressed as the concentration of the different elements determined by ICP-MS (independent variables). The results are shown in Fig. 1 a. Function 1 explained $46.9 \%$ of the variance and function 2 explained $35.9 \%$ of the variance, therefore the total of variance explained by these two functions was $82.8 \%$. The variables that contributed the most to the discriminant model were $\mathrm{Sr}$, $\mathrm{Ca}$, and Co positively, and $\mathrm{Zn}$, and $\mathrm{Ba}$ negatively (function 1 ) and $\mathrm{Mn}, \mathrm{K}, \mathrm{Ba}$, and $\mathrm{Cs}$, positively, and $\mathrm{Mg}$, negatively (function 2). The two discriminant functions showed a good separation between wines from white and red grape varieties (Fig. 1a). These discriminant functions allowed us to correctly classify $98.5 \%$ of the studied samples.

\subsubsection{Aging in oak versus young wines}

Fig. 1b showed the discriminant carried out with the data of the different element content from 2015 wines aged in oak barrels versus young wines produced in 2016 under the same conditions but without aging. Function 1 explained $62.9 \%$ of the variance and function 2 explained $29.0 \%$ of the variance, therefore the total of variance explained by these two functions was $91.9 \%$. The variables that most contributed to the discriminant model were $\mathrm{Na}$, positively, and $\mathrm{Cs}$, negatively (functions 1 and 2). The two discriminant functions showed a good separation between Graciano wines, aged \& young, but there was no difference between aged \& young wines of Tempranillo varieties (Fig. 1b). These discriminant functions allowed us to correctly classify $100 \%$ of the studied samples.

\subsubsection{Tempranillo wines produced with or without $\mathrm{SO}_{2}$}

The influence of the addition or not of $\mathrm{SO}_{2}$ to the wines was also studied (Fig. 1c). Function 1 (89.4\%) discriminated the samples according to $\mathrm{SO}_{2}$ addition whereas function 2 (9.5\%) discriminated the wines according to the storage in oak barrels, therefore the total of variance explained by these two functions was $98.9 \%$ (Fig. 1c). The elements that most contributed to the discriminant model were $\mathrm{Mg}, \mathrm{Pb}$, and $\mathrm{Cu}$, positively, and $\mathrm{Cs}$, and $\mathrm{Zn}$, negatively (function 1 ) and $\mathrm{Pb}$, positively, and $\mathrm{Cu}$, negatively (function 2 ). These discriminant functions allowed us to correctly classify $100 \%$ of the studied samples.

\subsubsection{Wines from different zones of the AOC Rioja all produced using Tempranillo blanco}

Fig. 2a showed the discriminant carried out using data of the different elements from Tempranillo blanco wines from five AOC Rioja zones (La Grajera, Valdegón, Cenicero, Corera, and Alfaro). Function 1 explained $86.5 \%$ of the variance and function 2 explained $7.7 \%$ of the variance, therefore the total of variance explained by these two functions was $94.2 \%$. The variables that most contributed to the discriminant model were $\mathrm{Sr}$, and $\mathrm{Ba}$, positively, and $\mathrm{Ni}$, and $\mathrm{Pb}$, negatively (function 1); and $\mathrm{Ni}, \mathrm{Pb}$, and $\mathrm{Ba}$, positively, and $\mathrm{Cu}$, negatively (function 2). Function 1 showed a good separation among wines from Cenicero zone and samples from the other four areas (Fig. 2a). These discriminant functions allowed us to classify correctly $100 \%$ of the studied 
a)

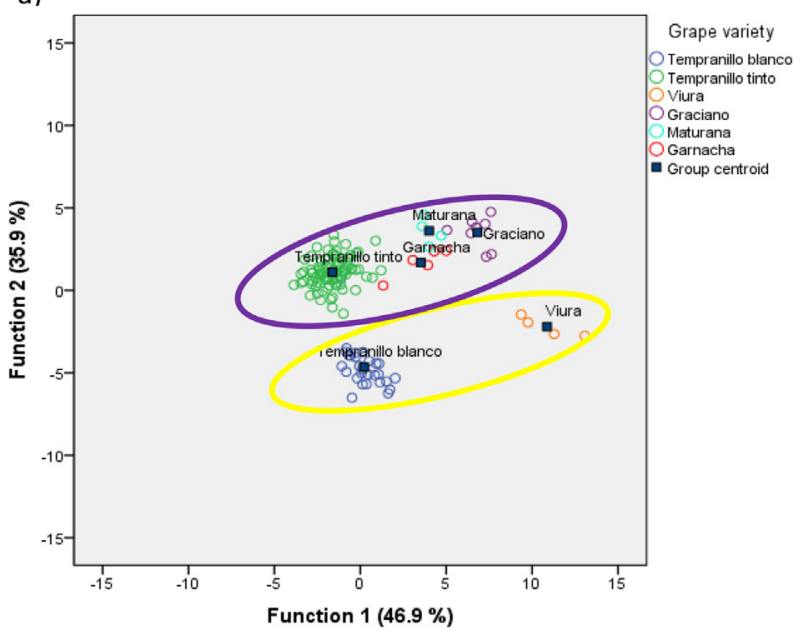

b)

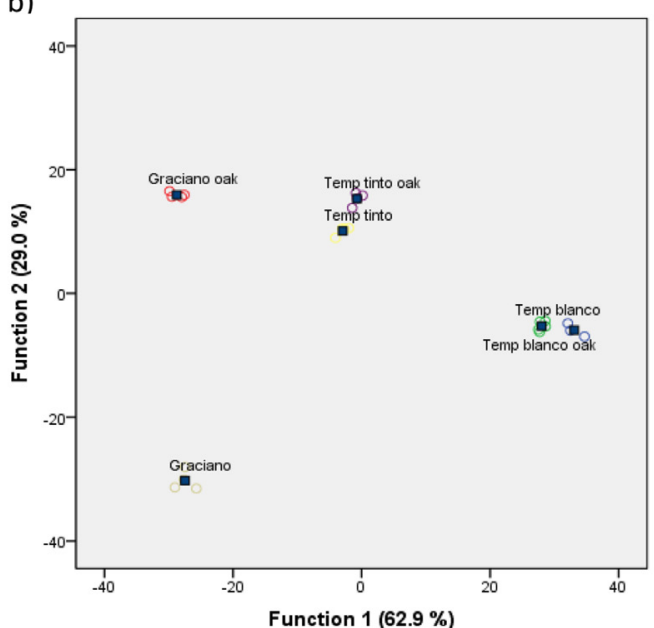

c)

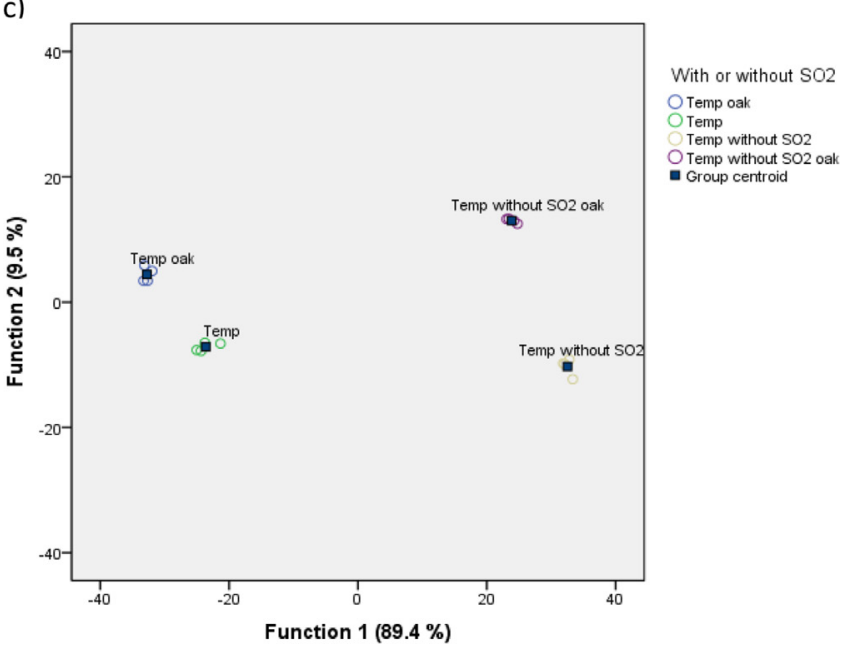

Fig. 1. Discriminant analysis performed on data expressed as concentration of the different elements determined by ICP-MS. a) Data of the different elements from wines produced using different grape varieties (Tempranillo blanco, Tempranillo, Viura, Graciano, Maturana, and Garnacha), b) wines produced in 2015 and aged in oak barrels versus young wines produced in 2016 under the same conditions as 2015 but without aging, c) wines with or without the addition of $\mathrm{SO}_{2}$. a)
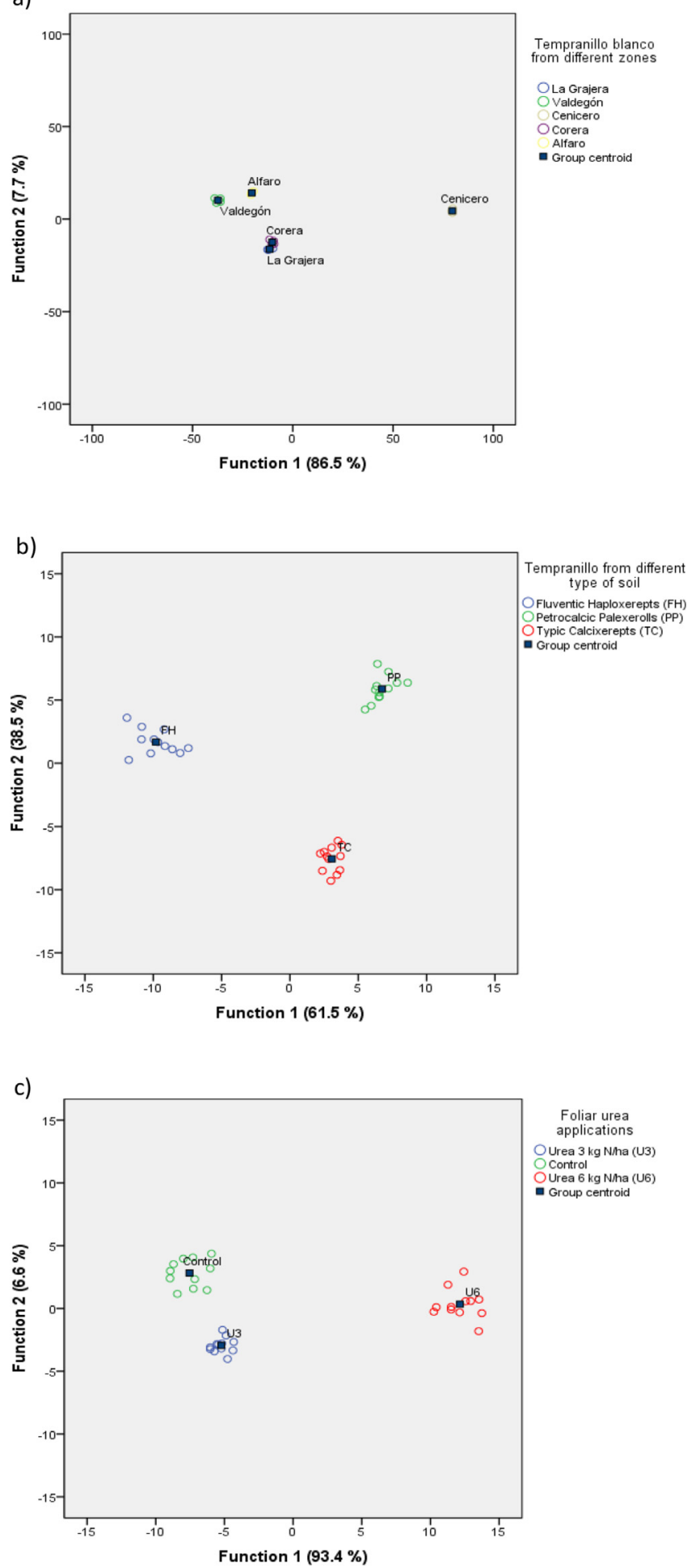

Fig. 2. Discriminant analysis performed on data expressed as concentration of the different elements determined by ICP-MS. a) Data of the different elements from Tempranillo blanco wines from five AOC Rioja zones (La Grajera, Valdegón, Cenicero, Corera, and Alfaro), b) wines produced at vineyards with different types of soil: Fluventic haploxerepts (FH), Typic calcixerepts (TC), and Petrocalcic palexeroll (PP), c) wines produced from three different concentrations (Control: 0; U3: 3 and U6: $6 \mathrm{~kg} \mathrm{~N} / \mathrm{ha}$ ) of urea applied on grapevine foliar tissues. 
samples. However, Šelih, Šala, and Drgan (2014) explained the unsatisfactory classification of the white samples using the PCA, where the first three principal components of the essay explained less than $50 \%$ of the variance, mainly due to the small distances between Slovenian wine-growing regions.

\subsubsection{Tempranillo wines from different types of soil}

The elements composition was used to distinguish between wines from vineyards with different types of soil: FH, TC, and PP, classified according to the Soil Survey Staff (2010). Function 1 (61.5\%) and function $2(38.5 \%)$ discriminated the samples according to the three types of soils, therefore the total of variance explained by these two functions was $100 \%$ (Fig. 2b). The elements that most contributed to the discriminant model were $\mathrm{Cs}$, and $\mathrm{Pb}$, positively (functions 1 and 2) and As, negatively (function 2). These discriminant functions allowed us to correctly classify $100 \%$ of the studied samples. Despite the complexity of the soil type distribution in Rioja region, successful classification from this small geographical vineyard area (the same municipality) was achieved by means of the ICP-MS procedures, such as in Coetzee et al. (2014). These authors also demonstrated the applicability of ICP-MS analysis for intraregional classification of wines, which came from different South African States. Therefore, the variability of trace element composition of the soils, depends on the distribution of soil types in the area.

\subsubsection{Tempranillo wines produced after the application of different nitrogen foliar treatments}

Finally, the effects of two different concentrations ( 3 and $6 \mathrm{~kg} \mathrm{~N} / \mathrm{ha}$ ) of the urea foliar applications on the wine mineral composition, were studied. Fig. $2 \mathrm{c}$ showed the discriminant carried out with the different elements content in the wines. Function 1 explained $93.4 \%$ of the variance and function 2 explained $6.6 \%$ of the variance, therefore the total of variance explained by these two functions was $100 \%$. The variables that most contributed to the discriminant model were $\mathrm{Pb}, \mathrm{Ni}$, and $\mathrm{Zn}$, positively, and $\mathrm{Mn}$, negatively (function 1 ); and $\mathrm{Mn}$, and $\mathrm{Ni}$, positively, and $\mathrm{Zn}, \mathrm{Ba}$, and $\mathrm{Fe}$, negatively (function 2). These discriminant functions allowed us to correctly classify $100 \%$ of the studied samples.

\section{Conclusions}

In order to analyze major, minor, and trace elements in red and white wines using inductively coupled plasma mass spectrometry (ICPMS), the best method was digestion with internal standard calibration for major elements; whilst the most of the minor and trace elements did not present significant differences between the four methods examined (standard addition and external calibration, with dilution and digestion). The content of these elements in the wines allowed their differentiation according to several factors. Thus, wines from the studied grape varieties were classified by $\mathrm{Sr}, \mathrm{Ca}, \mathrm{Mg}$, and $\mathrm{Mn}$ concentration. The wines from different geographical zones were differentiated according to $\mathrm{Sr}, \mathrm{Ba}, \mathrm{Ni}$, and $\mathrm{Cu}$. $\mathrm{Cs}$ and $\mathrm{Pb}$ were the main elements to discriminate the wines from the three soil types studied. Wines produced after several grapevine nitrogen foliar doses applications were classified by $\mathrm{Pb}$, $\mathrm{Ni}, \mathrm{Mn}$, and $\mathrm{Zn}$. The content of $\mathrm{Cs}, \mathrm{Mg}, \mathrm{Cu}$, and $\mathrm{Pb}$ in wines characterized the $\mathrm{SO}_{2}$ use in winemaking. Finally, wines aged in oak barrels were differentiated by $\mathrm{Na}$ and $\mathrm{Cs}$ concentration. The discriminant functions allowed us to classify correctly $100 \%$ of the studied wines with the exception of grape variety (97.0\%) and oak ageing (95.8\%). Therefore, ICP-MS analytical methodology could be a useful tool to fingerprint wines according to viticultural and oenological parameters.

\section{Acknowledgements}

This work has been supported by FEDER and National founds, through the Programa Operacional Regional do Alentejo (InAlentejo)
Operation ALENT-07-0262-FEDER-001871/Laboratório de Biotecnologia Aplicada e Tecnologias Agro-Ambientais and FEDER Funds through the Operational Programme for Competitiveness Factors-COMPETE and National Funds through FCT-Foundation for Science and Technology under the Project UID/AGR/00115/2013. T. Garde-Cerdán thanks the Spanish MINECO for funding her Ramón y Cajal contract. E.P. PérezÁlvarez thanks the Gobierno de La Rioja for her contract by the project R03-16. Raquel Garcia thanks the Fundação para a Ciência e Tecnologia (FCT) for a post-doctoral research fellowship (SFRH/BPD/109912/2015). We also want to thank J.B. Chávarri and J. Martínez, from the Gobierno de La Rioja, for providing us with the wines.

\section{Appendix A. Supplementary data}

Supplementary data associated with this article can be found, in the online version, at https://doi.org/10.1016/j.foodchem.2018.07.087.

\section{References}

Álvarez, M., Moreno, I. M., Jos, A. M., Cameán, A. M., \& González, A. G. (2007). Study of mineral profile of Montilla-Moriles "fino" wines using inductively coupled plasma atomic emission spectrometry methods. Journal of Food Composition and Analysis, 20, 391-395.

Brescia, M. A., Caldarola, V., De Giglio, A., Benedetti, D., Fanizzi, F. P., \& Sacco, A. (2002). Characterization of the geographical origin of Italian red wines based on traditional and nuclear magnetic resonance spectrometric determinations. Analytica Chimica Acta, 458, 177-186.

Castiñeira Gómez, M. D. M., Brandt, R., Jakubowski, N., \& Andersson, J. T. (2004). Changes of the metal composition in german white wines through the winemaking process. A study of 63 elements by inductively coupled plasma-mass spectrometry. Journal of Agricultural and Food Chemistry, 52, 2953-2961.

Cocchi, M., Franchini, G., Manzini, D., Manfredini, M., Marchetti, A., \& Ulrici, A. (2004). A chemometric approach to the comparison of different sample treatments for metals determination by atomic absorption spectroscopy in Aceto Balsamico Tradizionale di Modena. Journal of Agricultural and Food Chemistry, 52, 4047-4056.

Coetzee, P. P., van Jaarsveld, F. P., \& Vanhaecke, F. (2014). Intraregional classification of wine via ICP-MS elemental fingerprinting. Food Chemistry, 164, 485-492.

Eschnauer, H., Jakob, L., Meierer, H., \& Neeb, R. (1989). Use and limitations of ICP-OES in wine analysis. Mikrochimica Acta, 99, 291-298.

Fiket, Z., Mikac, N., \& Kniewald, G. (2011). Arsenic and other trace elements in wines of eastern Croatia. Food Chemistry, 126, 941-947.

Frías, S., Pérez Trujillo, J. P., Peña, E. M., \& Conde, J. E. (2001). Classification and differentiation of bottled sweet wines of Canary Islands (Spain) by their metallic content. European Food Research and Technology, 213, 145-149.

Frías, S., Conde, J. E., Rodríguez, M. A., Dohnal, V., \& Pérez-Trujillo, J. P. (2002). Metallic content of wines from the Canary Islands (Spain). Application of artificial neural networks to the data analysis. Die Nahrung, 46, 370-375.

Frías, S., Conde, J. E., Rodríguez-Bencomo, J. J., García-Montelongo, F., \& Pérez-Trujillo, J. P. (2003). Classification of commercial wines from the Canary Islands (Spain) by chemometric techniques using metallic contents. Talanta, 59, 335-344.

González-Hernández, G., Hardisson de La Torre, A., \& Arias Léon, J. J. (1996). Quantity of $\mathrm{K}, \mathrm{Ca}, \mathrm{Na}, \mathrm{Mg}, \mathrm{Fe}, \mathrm{Cu}, \mathrm{Pb}, \mathrm{Zn}$ and ashes in DOC Tacoronte-Acentejo (Canary Islands, Spain) musts and wines. Zeitschrift fur Lebensmittel-Untersuchung und Forschung, 203, 517-521.

Gonzálvez, A., Armenta, S., Pastor, A., \& De La Guardia, M. (2008). Searching the most appropriate sample pretreatment for the elemental analysis of wines by inductively coupled plasma-based techniques. Journal of Agricultural and Food Chemistry, 56, 4943-4954.

Iglesias, M., Besalú, E., \& Anticó, E. (2007). Internal standardization-atomic spectrometry and geographical pattern recognition techniques for the multielement analysis and classification of Catalonian red wines. Journal of Agricultural and Food Chemistry, 55, 219-225.

Ivanova-Petropulos, V., Wiltsche, H., Stafilov, T., Stefova, M., Motter, H., \& Lankmayr, E. (2013). Multielement analysis of macedonian wines by inductively coupled plasmamass spectrometry (ICP-MS) and inductively coupled plasma-optical emission spectrometry (ICP-OES) for their classification. Macedonian Journal of Chemistry and Chemical Engineering, 32, 265-281.

Ivanova-Petropulos, V., Jakabová, S., Nedelkovski, D., Pavlík, V., Balážová, Ž., \& Hegedû́s, O. (2015). Determination of Pb and Cd in Macedonian wines by electrothermal atomic absorption spectrometry (ETAAS). Food Analytical Methods, 8, 1947-1952.

Ivanova-Petropulos, V., Balabanova, B., Mitrev, S., Nedelkovski, D., Dimovska, V., \& Gulaboski, R. (2016). Optimization and validation of a microwave digestion method for multi-element characterization of Vranec wines. Food Analytical Methods, 9, 48-60.

Jakubowski, N., Brandt, R., Stuewer, D., Eschnauer, H. R., \& Görtges, S. (1999). Analysis of wines by ICP-MS: Is the pattern of the rare earth elements a reliable fingerprint for the provenance? Fresenius' Journal of Analytical Chemistry, 364, 424-428.

Jos, A., Moreno, I., González, A. G., Repetto, G., \& Cameán, A. M. (2004). Differentiation of sparkling wines (cava and champagne) according to their mineral content. Talanta, 
$63,377-382$.

Kment, P., Mihaljevič, M., Ettler, V., Šebek, O., Strnad, L., \& Rohlová, L. (2005). Differentiation of Czech wines using multielement composition - A comparison with vineyard soil. Food Chemistry, 91, 157-165.

Kruzlicova, D., Fiket, T., \& Kniewald, G. (2013). Classification of Croatian wine varieties using multivariate analysis of data obtained by high resolution ICP-MS analysis. Food Research International, 54, 621-626.

Lara, R., Cerutti, S., Salonia, J. A., Olsina, R. A., \& Martinez, L. D. (2005). Trace element determination of Argentine wines using ETAAS and USN-ICP-OES. Food and Chemical Toxicology, 43, 293-297.

McKinnon, A. J., \& Scollary, G. R. (1997). Size fractionation of metals in wine using ultrafiltration. Talanta, 44, 1649-1658.

Moreno, I. M., González-Weller, D., Gutierrez, V., Marino, M., Cameán, A. M., González, A. G., \& Hardisson, A. (2008). Determination of Al, Ba, Ca, Cu, Fe, K, Mg, Mn, Na, Sr and $\mathrm{Zn}$ in red wine samples by inductively coupled plasma optical emission spectroscopy: Evaluation of preliminary sample treatments. Microchemical Journal, 88, $56-61$.

Murányi, Z., \& Papp, L. (1998). "Enological" metal speciation analysis. Microchemical Journal, 60, 134-142.

Murányi, Z., \& Kovács, Z. (2000). Statistical evaluation of aroma and metal content in Tokay wines. Microchemical Journal, 67, 91-96.

Orescanin, V., Katunar, A., Kutle, A., \& Valkovic, V. (2003). Heavy metals in soil, grape, and wine. Journal of Trace and Microprobe Techniques, 21, 171-180.

Orvini, E., Speziali, M., Salvini, A., \& Herborg, C. (2000). Rare earth elements determination in environmental matrices by INAA. Microchemical Journal, 67, 97-104.

Pan, X.-D., Tang, J., Chen, Q., Wu, P.-G., \& Han, J.-L. (2013). Evaluation of direct sampling method for trace elements analysis in Chinese rice wine by ICP-OES. European Food Research and Technology, 236, 531-535.

Pérez-Álvarez, E. P., Garde-Cerdán, T., García-Escudero, E., \& Martínez-Vidaurre, J. M. (2017). Effect of two doses of urea foliar application on leaves and grape nitrogen composition during two vintages. Journal of the Science of Food and Agriculture, 97, $2524-2532$.
Pohl, P. (2007). What do metals tell us about wine? TrAC-Trends in Analytical Chemistry, 26, 941-949.

Pyrzynska, K. (2007). Chemical speciation and fractionation of metals in wine. Chemical Speciation and Bioavailability, 19, 1-8.

Rodrigues, S. M., Otero, M., Alves, A. A., Coimbra, J., Coimbra, M. A., Pereira, E., \& Duarte, A. C. (2011). Elemental analysis for categorization of wines and authentication of their certified brand of origin. Journal of Food Composition and Analysis, 24, $548-562$.

Rodríguez Mozaz, S., García Sotro, A., Garrido Segovia, J., \& Ancín Azpilicueta, C. (1999). Influence of decantation of viura must on the cation content. Evolution during wine fermentation and stabilization. Food Research International, 32, 683-689.

Rusjan, D., Strlič, M., Pucko, D., Šelih, V. S., \& Korošec-Koruza, Z. (2006). Vineyard soil characteristics related to content of transition metals in a sub-Mediterranean winegrowing region of Slovenia. Geoderma, 136, 930-936.

Sauvage, L., Frank, D., Stearne, J., \& Millikan, M. B. (2002). Trace metal studies of selected white wines: An alternative approach. Analytica Chimica Acta, 458, 223-230.

Šelih, V. S., Šala, M., \& Drgan, V. (2014). Multi-element analysis of wines by ICP-MS and ICP-OES and their classification according to geographical origin in Slovenia. Food Chemistry, 153, 414-423.

Soil Survey Staff (2010). Keys to soil taxonomy (11th ed.). Blacksburg, Virginia: Pocahontas Press.

Šperková, J., \& Suchánek, M. (2005). Multivariate classification of wines from different Bohemian regions (Czech Republic). Food Chemistry, 93, 659-663.

Thiel, G., \& Danzer, K. (1997). Direct analysis of mineral components in wine by inductively coupled plasma optical emission spectrometry (ICP-OES). Fresenius' Journal of Analytical Chemistry, 357, 553-557.

Voica, C., Dehelean, A., \& Pamula, A. (2009). Method validation for determination of heavy metals in wine and slightly alcoholic beverages by ICP-MS. Journal of Physics: Conference Series, 182, 012036.

Williams, J. G., Jarvis, K. E., \& Wills, J. D. (1992). Inductively coupled plasma mass spectrometry: Application to the analysis of wines. Journal of Wine Research, 3, 59-62. 